\title{
STATE AND LOCAL IMMIGRATION REGULATION IN THE UNITED STATES BEFORE I 882
}

The absence of significant federal regulation in the area of immigration legislation until i $882^{1}$ no more denotes a laissez-faire approach in this area than in many other aspects of American economic life. For many generations Congress had left the task of regulating the immigrant stream to the states and localities. ${ }^{2}$ The first general federal law (1882) is best understood in the context of antecedent activity on the local level. Eventually most of the seaboard states, including many without an important passenger traffic, enacted statutes dealing with immigration. Table I presents a brief outline of their essential features.

After a consideration of certain aspects of the provisions of these laws, their administration in the major seaports will be surveyed. It will then be shown how the increasing opposition by business interests to state legislation, culminating in decisions by the Supreme Court declaring such regulation unconstitutional, eventually paved the way for the 1882 Act of Congress.

\section{THE STATUTORY BACKGROUND}

Nine of the thirteen colonies reflected in their enactments the desire to protect the community from the burden of foreigners likely to

1 Federal space and sanitation requirements, however, date back to I819. Federal legislation is conveniently compiled in U.S. Immigration Commission, Reports, vol. XXXIX (Washington, I9I I). Cf. John Higham, Strangers in the Land (New Brunswick, N. J.; Rutgers University Press, 1955), p. 44. This article does not discuss legislation enacted in a number of states which barred foreign convicts. - The author acknowledges with gratitude the many helpful suggestions made by Professor Carter Goodrich, who supervised his doctoral thesis "Public Poor Relief in America, $1790-1860$ " (Columbia University, I952) from which much of the material for this article is taken. A grant from the Social Science Research Council through the Committee on Research in Economic History made possible the research for this thesis.

2 Cf. Leonard D. White, The Jacksonians; A Study in Administrative History I829-I86I (New York: Macmillan, 1954), p. 507. 
become public charges (See Table). As early as I658 New Plymouth ordered vessel-masters to carry back whence they came persons who might be "chargeable or burthensome to the plantation" and who had not received permission to reside there. A similar requirement in the I 683 poor law of New York affected passengers without property or "manuall craft or occupaceon" who could not give security "for their well demeanor". ${ }^{1}$ Later in New York and in other colonies, the vessel master had the alternative of removing the stranger or giving a bond to indemnify the public against the possible expense of supporting him. Although the laws in the nineteenth century generally made no specific reference to removal it was not unknown for steamship companies to return passengers who had become public charges. ${ }^{2}$

Pennsylvania was first to place a head tax on immigrants by a shortlived act (1729) aiming to discourage the importation of persons likely to become chargeable. During the nineteenth century, many states, including every one with an important seaport, allowed for a time at least, the payment of a flat amount per immigrant in lieu of a bond. The option of a tax or a bond lay with the town in Maine, New Jersey, Pennsylvania (1828-1849) and California, and with the vessel master in Massachusetts ( $1831-1837$ ), Rhode Island, and Maryland (1 833 -I 835 ). In Massachusetts (1837-1 849) and New York (1847-I 849) the ship owner had to bond defective passengers and pay the head money for the others. Delaware (1 829 on), Maryland (1835-I 849) and Louisiana (1 842-1 849) had no provision for bonding; the passenger

1 David Pulsifer (editor), Records of the Colony of New Plymouth... Laws 1623-1682 (Boston, 1861), p. 108. In 1638 the vessel master was required to return any passenger landed without the permission of the authorities to the place from whence he came. (Ibid. p. 30.) In the 1672 Book of General Laws, the vessel master had the option of giving a bond in lieu of temoving the person likely to be chargeable. (New Plymouth, The Compact with the Charter and Laws [Boston, I836], p. 273). - N.Y., 1683, c. 9, again in 1691, c. 6. (All references to Sessional Laws here are by state, year enacted, and chapter). These laws, unlike eighteenth century legislation, made no provision for a bond by the vessel master and therefore are not included in our table.

2 The option of removing a passenger feared likely to become chargeable was specified in the N.H. acts of 1718 and 1791 , the Mass. law of 1700 , the R.I. law of 1702 , the N.Y. acts of 1683,1721 and 1788 , the N. J. law of 1730 , the Pa. laws of 1730 and 1803 , the Del. laws of 1740 , 1775 and 1791 (c. 218 , sec. 17 ), the N.C. law of 1738 . The Pa. law of 1803 and the Miss. Territory Act of 1803 , retained in Ala. until 1852 , and in Miss. until 1857 were the only ones passed during the nineteenth century which specifically stated the alternative of removing the passengers or bonding them. As early as 1722 Mass. dropped reference to this alternative (though it was implied in the $1756 \mathrm{act}$ ) and R.I. did so in 1729 . For the removal practices of the Cunard and Allan Lines see (National Board of Trade), Freedom of Immigration, Statements Presented at a Hearing Before the Committee on Commerce of the House of Representatives, at Washington, December 14, I s, 16, 1876, in opposition to the imposition of a headmoney tax on alien passengers arriving at all the ports of the United States (Boston, 1876), p. 29, 30. Hereafter cited as Freedom. 
tax had to be paid for every immigrant. When the Massachusetts act was declared unconstitutional in 1849 , several states amended their laws. Massachusetts and New York gave the vessel master an option between a bond or commutation money for healthy passengers (and later on, for all passengers); Pennsylvania, Maryland and Louisiana offered the alternative for all immigrant passengers. ${ }^{1}$

The scope of the immigrant laws tended to become more comprehensive with the passage of time. At first concerned only with foreigners who were candidates for the pauper class, they later affected everyone from abroad, with a view to securing adequate revenues to support the foreign poor. ${ }^{2}$

Connecticut, Oregon, and Washington, which had no foreign passenger traffic to speak of, were the only seaboard states never to have legislated on the subject, while North Carolina's law was in effect for only a few years in the mid-eighteenth century. In 1819 Virginia introduced a provision that a vessel master landing a passenger who could not maintain himself for one month was to be fined $\$ 50$; Florida followed suit in $1822 . .^{3}$ Starting in 1866 Texas did not allow

1 A 1740 law of Del. (Laws, I, c. 66, sec. 7) placed a charge of $6 \mathrm{~d}$. (7 cents) per foreigner, for a certificate that the person was fit to be landed. Under a 1797 act (Laws, II, c. I34, sec. 7), the physician examining forcign passengers was directed to collect 6 cents from each for the use of the poor in the county where the money was collected. - N. J.'s act of 1838 - unlike the laws of other states - did not specify the alternative of a bond or head money, but such it was in fact. Thus in the Rev. St., 1847 , the head money provision was in Tit. I, c. 4 while the bond was referred to in Tit. 32, c. I, sec. 32. - The laws of Me. and $\mathrm{N}$. J. which left it to the town whether a commutation should be made, as well as the Del. law of 1829 , were not changed in 1849 or subsequently, and would appear to have been unconstitutional in the light of this decision. - In 1854 Portland adopted a form of receipt which specified that the vessel owner was paying the commutation money in lieu of the bond, at his request, and he agreed never to sue for a recovery of the amount paid. (Portland, The Charter and Ordinances... [Portland, 1856], p. 28).

2 R. I. was the only colony whose laws covered non-defective as well as defective persons, though for a time Mass. (1 722-1 724) and Pa. (x 729) did so also. N.Y. (1799) was first, and N.J. (1838) was last, to widen the scope of the laws. S.C. was the only state which never changed its earliest act $(1730)$, retained in Rev. St., 1873 , c. 29 , Sec. 24 . - The N.Y. and $\mathrm{Pa}$. laws were extended in scope to include not only foreigners but Americans as well. La.'s i 842 law taxed boats from American as well as from foreign ports, as did Cal.'s law of 1850 . - Not only vessel owners but also railroads were responsible, for one year after carrying a foreigner into the state in Mass. (1 $85 \mathrm{I}$, c. 342); and R.I. (June, 1847 ).

${ }^{3}$ From 1784 to 1796 , though, a foreigner residing in Conn. who was likely to become chargeable, could be sent away at state expense, if the cost was not greater than "the Advantage of such Transportation". (Conn., I784, p. 82). - Va., Rev. Code, I819, c. 245, sec. 8 , retained in the 1887 Code, sec. 2003 . An earlier act, Oct., I $748, c .17$, sec. 7 provided for a $£$ ro $(\$ 33.33)$ fine for landing or discharging a sick or disabled sailor without providing for his maintenance. The I $_{8}$ I $_{9}$ Code (c. 245 , sec. 8) increased the fine to $\$ 60$, and so it remained to the end of our period. - Fla., 1822, p. 63. This act also provided for a $\$ 100$ fine for landing a disabled seaman. The same provisions were still in effect in $188 \mathrm{I}$. (Fla., Digest I82I-188I, c. I II, sec. 7). 
physical or mental defectives, or persons who had been paupers or criminals to land. ${ }^{1}$

Within the legislative framework described above, localities grappled with some of the problems raised by foreign immigration. Of particular interest are the provisions made in the various ports for easing the adjustment of the immigrants and the complication interposed by commercial rivalry, in various communities' attempts to finance these facilities by special taxes on passengers.

\section{LOCAL PROVISION FOR IMMIGRANTS}

New York City, confronted with a "prodigious influx of indigent foreigners" wanted the state to support the foreign poor. ${ }^{2}$ Such distinguished governors as John Jay (1796) and DeWitt Clinton (1 827) had acknowledged the justice of the claim, but until 1847 the state limited its assistance to the proceeds of the auction duty collected in the city (1798-18 I6), and later to a $\$ 10,000$ yearly appropriation. ${ }^{3}$ As early as 1797 , however, the state opened a Marine Hospital on Staten Island which admitted sick seamen and foreigners who were ill upon their arrival. The institution was supported by a tax on everyone on board each vessel entering New York harbor from a foreign port. The collection of "hospital money" by the state ceased when it was declared unconstitutional in $1849 .^{4}$

1 Tex., I 866, c. 38 .

21796 statement of the Almshouse Commissioners in N.Y.C., Minutes of the Common Council, II, 21 2. Hereafter cited as NYCMCC. A similar complaint was made by the commissioners in the petition City of New York SS. At a meeting of the Common Council... the I 9 th of January 1798 ... (Broadside, Houghton Library, Harvard University). ${ }^{3}$ New York State. Messages from the Governors... II, 365; III, 177. These governors, as well as a committee of the state assembly (Journal, $1827, \mathrm{pp} .604$-605) proposed that all the counties with a foreign pauper burden should be assisted. See also N.Y. Society for the Prevention of Pauperism, Second Annual Report, pp. 24-25.

${ }_{4}^{4}$ N.Y., 1797, c. 67. Each vessel master and cabin passenger paid $\$ 1$; each mate and steerage passenger paid 50 cents, and every sailor, 25 cents. $18 \mathrm{I}$, c. 175 , sec. 26 . Under the $18 \mathrm{r} 1$ law, masters and sailors on coasting vessels paid only 25 cents. N.Y., I 843 , c. 213 , made the rate for the first category $\$ 1.50$, for steerage, 25 cents, and for mates or sailors, so cents. 1844 , c. 316 charged masters $\$ 1.50$, cabin passengers $\$ 2.00$, stcerage, mates, and sailors, $5 \circ$ cents. 1845 , c. 227 retained the previous rate for captains, cabin, and steerage passengers, but raised the 1844 tax on sailors from so cents to $\$ \mathrm{I}$. 'The hospital tax was eliminated by 1849 , c. 350 , shortly after the Supreme Court decision, Infra, p. 287. David Schneider points out that hospital money was not used for foreigners who needed relief other than medical care upon their arrival. The History of Public Welfare in New York State I 609-1 866 (Chicago: University of Chicago Press, 1938), p. 304. Under an I 846 law, though, c. 300 , sec. 18 repealed by 1849 , c. 350 , sec. I , a person who had paid hospital money could be admitted to the Marine Hospital for a temporary illncss, at any time within a year of his arrival. The 1797 law provided that any surplus hospital money was to go to the Society of the Hospital of the City of New York, for the care of sick scamen and foreigners, but later legislation deffected the surplus to the Institution for the Reformation of Juvenile Delinquents in New York City $(\$ 8,000$ a ycar $)$ and three city dispensaries (\$ I,500 each). N.Y.S. Senate, Documents I 845, I, No. 29, p. 2. 
Meanwhile New York City had been empowered to take a bond for every newly arrived foreigner (1799). In December, I 8 I 7 , the vessel owner was given the option of commuting the bond for $\$ s$ a passenger, except in cases where it would be "injurious to the public interest".

Commutation was not allowed in all cases, because of the fear that this would induce foreign governments to dump their paupers here at little trouble and expense. The rate, cut to $\$ 3$ in August i 8 I 8, but restored to $\$ S$ in October 1819 , was halved in 1826 and further reduced to $\$ I$ in 1830 in accordance with the request of the merchant class, and the desire of the city council to encourage commutation. Finally in 1832 , the mayor was given latitude to commute at from $\$$ I to $\$ 10$ in those cases where he considered it expedient. ${ }^{1}$

The heavy penalty ( $\$ 500$ per person) for landing a foreigner within fifty miles of the city for the purpose of evading the law did not deter some vessel masters from dropping anchor elsewhere, particularly at nearby Perth Amboy, New Jersey, where no immigrant requirements were in effect. ${ }^{2}$ Municipal authorities complained about the practice already in 1810 ; in 1838 New Jersey authorized its localities to collect from $\$ \mathrm{I}$ to $\$$ io for every alien landed. ${ }^{3}$ An 1837 Newark ordinance required a $\$ 300$ bond for one year for every alien "pauper, vagrant, sick, infirm or insane person", but made no provision for a

1 NYCMCC IX, 4II, 777; X, 590; XV, 643; XIX, 147-1 50. For the 1832 ordinance see Board of Assistant Aldermen, Proceedings, I, 352. See also Comptroller, Annual Statement... 1845 (New York, I 846), p. 33.

2 For early complaints about Perth Amboy, see NYCMCC, II, 351, 74r, 761. An English investigation revealed that ships bound for New York with "a very low description of emigrants" would go to Amboy instead, and packet boats would bring the aliens to the metropolis. (Great Britain, Parliamentary Papers, 1826, IV, 184). Official data, first collected for 1819-1820, showed that 89 foreigners arrived at Perth Amboy in the year to September 30,1821 , and none thereafter until 1829 , when Ios arrivals were listed; the number was 74 in 1830,57 in 1831,545 in 1832 , and none again until 1836 , when 494 entered. A peak of 5,006 arrived in 1837 , and none in subsequent years, according to this source. All data on arrivals used in this study are from U.S. Treasury Department Bureau of Statistics, Tables Showing Arrivals of Alien Passengers and Immigrants in the United States from 1820 to 1888 (Washington, 1889 ), pp. 108-109. - When 36 ill passengers arrived in Perth Amboy in 1837 on the "Phoebe", $\$ 200$ bonds were given for each one. (Perth Amboy adsm. Smith. 4 Harrison [N.J.], 53 [1842]).

3 Board of Aldermen, Documents, V, No. 1, pp. I 5-I6. It would appear likely that localities did collect head money, as the 1838 act authorizing this also provided that the locality where the alien had been permitted to land was responsible for relieving him if he afterwards became sick or otherwise incapable of maintaining himself. - Newark, Charter of the City... with the Ordinances passed by the Common Council (Newark, I 850), p. 56; the same provision was included in Newark, The City Charter and Ordinances... (Newark, I 858 ), p. 262, and in An Ordinance Comprising the Ordinances... (Newark, 1890), pp. 229-230. Perth Amboy Minutes of the Governing Body, November 7, 1860 (MS). I am indebted to Philip P. Costello, City Clerk, for this reference. - Portland, Annual Reports... 1856-1857, p. 40. Freedom, p. 3 r. 
head tax. Nearby Perth Amboy had a commutation fee of one dollar per passenger from a foreign port in $\mathrm{I} 860$.

Vessel masters could (and usually would) take out bonds for their passengers for a nominal sum from brokers who specialized in the business. ${ }^{1}$ Bondsmen paid the cost of caring for the foreigners at the New York City almshouse, but the city had the trouble of ascertaining who was responsible for the pauper. Sometimes the pauper forgot the name of the vessel on which he came, or his identity was so disguised on the passenger list that it was impossible to identify him. ${ }^{2}$ Enterprising bondsmen found it more profitable to establish private poorhouses and hospitals than to pay the city. So great were the abuses under this arrangement that at last public opinion was aroused in favor of a fundamental reform which took responsibility for the care of the immigrant poor out of the hands of the city almshouse commissioners where it had rested since colonial times. ${ }^{3} \mathrm{~A}$ state board, the Commissioners of Emigration, was established in May, I847, composed of the mayors of New York and Brooklyn, and the presidents of the German and Irish Societies, ex officio, as well as six others appointed by the governor. All healthy, self-supporting passengers had to pay a head tax. Almost \$ i I,250,000 had been collected in the thirty years before the tax was declared unconstitutional (1 876 ). ${ }^{4}$

These moneys supported a vast network of services: the Castle Garden depot, the Marine Hospital (used only for infectious diseases after I 849), hospitals and refuges on Ward's Island in the East River worth an estimated $\$ 3,000,000$ in I $88 \mathrm{I}$, and an employment office on Canal Street (Manhattan) which also sheltered jobless immigrants.

I From 1843 to May, I847, 294,755 passengers were bonded, while only 34,707 were commuted. (N.Y.C. Comptroller, Annual Statement... 1845, p. 62; N.Y.C. Almshouse Commissioner; Annual Report... I846, p. 398; ibid... 1847, p. 41). Passengers were bonded by brokers at a cost to the vessel-owner of from Io cents (or less) to $\$$ I per passenger; from 1828 to 1836 the price was $\$ 2$ per vessel. (Friedrich Kapp, Immigration and the Commissioners of Emigration of the State of New York [New York, I 870], pp. 45-46). Several bondsmen had commitments for over $\$ 1,000,000$ each (N.Y.C. Comptroller, op. cit., p. 32 ). In "many instances", it was reported in 1830 , the bonds could not be collected. (NYCMCC, XVIII, 575).

${ }^{2}$ N.Y.C. Comptroller, ibid., pp. 32-33. Thus from 1843 through 1845 , the city received just under $\$ 20,000$ from bondsmen .

${ }^{3}$ N.Y.C. Board of Assistant Aldermen, Proceedings and Documents, XXVII, ir 5 . Conditions at Tapscott's are described in ibid., 117 ff. See also Kapp, op. cit., pp. 50-60. ${ }^{4}$ N.Y. Commissioners of Emigration, Annual Report i 881, p. I 2. The background of the I 847 law is discussed in Kapp, op. cit., pp. 85-95. For annual statistics of head money collections sce N.Y. (State) Commissioners of Emigration, Annual Reports... from... I 847 , to 1860 , inclusive (New York I 861 ), pp. 355-377. This volume is cited hereafter as N.Y. Com. Emig.. Data for 1818 through 1833 is in N.Y.C. Board of Aldermen, Documents, I, I 84 . For the years $1834-1847$ see N.Y.C. Comptroller, Annual Report, passim. 
From May, I 847, to the end of i 875 , over 500,000 immigrants had been cared for in these institutions, a slightly smaller number had been fed and lodged temporarily and supplied with cash relief in the city, and another 250,000 had been relieved and provided for in various county institutions elsewhere in the state, at the Commission's expense. ${ }^{1}$ Until 1876 these extensive activities were sustained entirely by the immigrants. From i 876 to i 882 (when the Federal government took action) the state's taxpayers spent over one million dollars for the immigrant institutions. ${ }^{2}$

The law establishing the Commissioners of Emigration sought to incorporate the immigrant into the labor force with the greatest possible speed. Accordingly, the Commissioners were empowered to spend money on moving foreigners to any part of New York or any other state. Many destitute persons were given the fare to help them reach a locality where their labor was in demand. By the end of 1875 over 58,000 persons had been forwarded to a destination in the United States or returned to Europe at their own request. ${ }^{3}$

Another aspect of the Commissioners' work was the placement of immigrants. From I 847 on, many able-bodied among them were given jobs on the public works, after the board had contacted the contractors. An "Intelligence Office and Labor Exchange" was opened in December, 1850 . Over I 8,000 persons were given temporary relief and placed on jobs in the first year of operation. By I 876 , over 400,000 placements had been made. ${ }^{4}$

The Commissioners sought to shield the newly-arrived foreigners from imposition and abuse. At the Quarantine Station an officer boarded the ship to receive complaints as well as to ascertain the number of passengers. Once at Castle Garden, a physician checked for any cases which might have escaped the notice of the Quarantine

1 N.Y. Commissioners of Emigration, Annual Report, I876, p. 70. Every alien landed in towns on the Great Lakes, Niagara River, or the St. Lawrence had to pay $\$$ I to the county superintendents of the poor (N.Y., 1847 , c. 431). Later the vessel master could pay $\$$ I or give a $\$$ soo bond for five years for every alien ( 1849, c. 405 ; retained in Rev. St., 7 th ed. [188 r], Pt. I, C. 20, Title $21 \mathrm{~B}$ ). The county receiving payment was to reimburse any locality in the statc where the alien became a pauper within three years after landing.

2 N.Y. Commissioners of Emigration, Annual Reports, I88I, p. 12. N.Y.S. Assembly, Documents 1851 , No. 92, pp. 7-8; N.Y.S. Senate, Documents 1856 , III, No. 105, p. I4. To a member of the Know Nothing party, "the plea that the commutation tax paid by immigration supports this aggregation of moral filth in our community, is paltry, if not meanly mercenary..." (Thomas R. Whitney, A Defense of the American Policy as Opposed to the Encroachment of foreign influence [New York, 1856], p. 185).

3 N.Y., I 847 , c. I95, sec. 4 ; N.Y. Com. Emig. p. 52, 74, 116, 270 . Ibid., Annual Report I 876, p. 70 .

4 N.Y. Com. Emig. pp. 6-7, 51-52, 77-78; Ibid., Annual Report I 876, p. 70. 
authorities; these were to be hospitalized. He also decided when special bonds would be required, but in later years (because of pressure from the shipping interests) these were discontinued. Railroad agents sold tickets under the watchful eye of the Commission, while brokers exchanged foreign for American money at rates which were posted conspicuously. For the immigrant who intended to remain in the city a privately run baggage delivery service was available at a fee approved by the Commission. Licensed boarding house keepers were permitted to solicit trade under supervision. An information bureau announced the names of friends in the waiting room and distributed letters and funds. Therc was even a letter-writing bureau staffed by clerks familiar with foreign languages. Castle Garden, in short, was a miniature welfare state. ${ }^{1}$ New York City, it could be written in 1869 , was "par excellence the city of immigrants - the city in which of all others in the world, the immigrant is most welcome and most secure." 2

Only Massachusetts came close to rivaling the elaborate provisions made by New York. Handbills and placards posted in various parts of the United Kingdom were said to have proclaimed, as a further encouragement to emigration, that the Bay State gave a "luxurious support" to poor foreigners. ${ }^{3}$

Prior to i 80 , Massachusetts cities pocketed the proceeds of the alien passenger tax they collected and used it for the support of the foreign poor. Under the law of $\mathrm{I} 840$, however, the localities were required to pay over to the state all balances left in their treasuries from this source. Further centralization was achieved in 1848 when the governor appointed for each port a superintendent of alien passengers who remitted to the state treasurer all moneys received from foreigners in excess of his salary. Finally, in $185 \mathrm{I}$, the state Board of Commissioners of Alien Passengers and State Paupers was created - made up of one member of the Governor's Council, the state auditor and the superintendent of alien passengers for Boston. The board administered the emigration and state pauper laws. The Hospital on Rainsford Island in Boston Harbor for immigrants who were sick on their arrival was

1 N.Y. Commissioners of Emigration, Annual Report... I 868, pp. 19-22. For engravings describing the various activities at Castle Garden, see Frank Leslie's Illustrated Newspaper, January 20,1866, pp. $280-28 \mathrm{I}$. The discontinuance of special bonds is referred to in N.Y.S. Assembly, Documents 1876, IV, No. 33, p. 555 .

${ }^{2}$ C. T. Hopkins, Common Sense Applied to the Immigrant Question (San Francisco, 1869), p. 3 I.

3 Mass. Senate, Documents 1847 , No. 109, p. 2. See also ibid., Documents 1846 , No. 74 , p. 3 . 
renovated and placed under the board. After 1854 the board maintained the foreign poor at the three state almshouses it had acquired. ${ }^{1}$

Rather than pay the $\$$ s required under the i 83 I Massachusetts law, most vessel owners preferred to bond their passengers. Boston collected only a few hundred dollars until 1837 when the payment of head money for healthy aliens was made compulsory. In the next dozen years a total of $\$ 160,000$ in head money was received, and from I 848 to 1872 (when the state discontinued the tax) almost $\$ 640,000$ more. Here too it was found difficult to collect on the bonds which had been given, because of the problem of getting the correct names of the foreigners, and, even more important, of proving their identity. ${ }^{2}$ The Alien Commissioners were authorized to cancel old bonds on reasonable terms, and willingly accepted, on average, less than $\$ 2$ per bond. ${ }^{3}$ In the 1850 's the Commissioners found it worthwhile to commute the $\$ 1,000$ bonds for persons likely to become chargeable, at $\$ 5$ to $\$ 30$ each. ${ }^{4}$ The head money collections of Massachusetts covered about half of the cost of caring for foreigners who became public charges within five years after landing. ${ }^{5}$ At its own expense the Cunard Line maintained facilities for the protection of immigrants from imposition at its Boston wharves. ${ }^{6}$

Philadelphia ranked fourth as an Atlantic coast immigration depot, admitting less than half of the 864,000 who came ashore at Boston, and only $5 \%$ of the more than $8,500,000$ foreigners who disembarked 1 Mass., I 840 , c. 96 , sec. 2 ; 1845 , c. $76 ; 1848$, c. 3 1 3.185 I, c. 342 created the state board. The Rainsford Hospital is referted to in 1852 , c. 275 , sec. 11 ; 1853 , c. 352 , sec. 5 ; 1854 , c. 189 , sec. 6 .

2 Mass. House of Representatives, Documents 1835 , No. 6o, p. I 1, 21. Mass. Board of State Charities, Thirteenth Annual Report, pp. 23-24. See Boston Auditor, Annual Report of Receipts and Expenditures, I832-I849, passim, and Mass. Board of State Charities, Seventh Annual Report... (Boston, I871), p. 237, for the annual statistics of head money collection. - The Boston superintendent of alien passengers admitted in 1847 that he had allowed sick and aged persons to land without requiring a bond, and those persons went directly to the almshouse. Infirm persons were allowed to land without being bonded, if they stated they had friends here who could support them. The superintendent defended his conduct on the grounds of humanity alone. (Mass. Senate, Documents, 1847 , No. IO9, pp. 8-9).

${ }^{3}$ Mass., 1853, c. 367 . There were 6,757 bonds outstanding which had been collected since 1848 . In 1853 bonds for 2,629 persons were cancelled, for a commutation of $\$ 5,034$; in 1854 another 716 bonds were cancelled for $\$ 1,213$.

4 Mass. House of Representatives, Documents 1856, No. 4I, p. I9; ibid., 1857, No. 30, p. 2 I.

5 Statement of F. B. Sanborn, Proceedings of the Conference of Charities... Detroit, May, 1875 (Boston, 1875 ), p. 97. From 1854 to 1858 over $\$ 86,000$ was collected in Boston, while the cost of supporting foreigners at the state almshouse during these years amounted to $\$ 56,000$. (Mass. House of Representatives, Documents 1859, No. 243, p. 4).

6 Freedom, p. 28. 
in the rival port of New York in the years from 1820 to 1882 . In lieu of a bond, Philadelphia preferred to collect head money. The rate was $\$ 2.50$ per alien, from August, 1828 to May, 1832 , and again from August, 1837 to June, 1842 , and only $\$ 1.50$ was charged from May, I 832 to August, I 837 , and again beginning in June, 1842 . After much pressure had been exerted by the ship-owners, it was lowered to $\$$ I in $1849 .^{1}$

Several early examples of the poor officials' ("guardians of the poor") attention to chargeable immigrants may be cited. In April, 1798 the guardians delegated one of their numbers "to attend the case of John McNarney, an Irish lad subject to Fits", who had been landed at New Castle, Delaware, and to obtain reimbursement for the support of a couple who had come from Hamburg on the brig "Mary". The master of the schooner "Juliana" was compelled by court action (I807), to enter into a \$ 1,500 recognizance "for having imported two maimed negro convicts from Paramaribo judged likely to become chargeable". The agent of a vessel from Belfast gave $\$$ Ioo for the support of a pauper who had come over on it (1810). ${ }^{2}$

In 1827 a committee of guardians noted a progressive increase in the number of foreigners burdening the city; the citizens "unresistingly suffer it to become the reservoir into which Europe may pour her surplus of worthlessness, improvidence, and crime... [displaying] a degree of forbearance and recklessness altogether inexcusable". At the same time, a citizens' committee blamed the "loose and ineffective" regulations of the city for the disproportionate foreign pauper burden borne by it. ${ }^{3}$ The head tax provision in the 1828 poor law does not

1 For the commutation fees, sec Philadelphia Guardians of the Poor, Minutes (Ms, Phila. General Hospital, Old Blockley Historical Museum); hereafter cited as Phila. GP, XXII, July 3, I837; XXIII, June I3, I842; XXVI, August 14, 1849. The $\$$ I fee was retained in the Rules for the Government of the Board of Guardians adopted May, I 85 I (Philadelphia, I85 I), p. 18. - Within a few months after the passage of the I 828 law, the consignees of a vessel from Le Havre with 200 aliens on board, wanted to bond them instead of paying head money, but the guardians refused to allow this. (Phila. GP, XVIII, October 13, 1828). In 1839 the solicitor stated that if taking bonds "would be more acceptable and less onerous (to vessel owners)... it would be conformable to the intention of the Legislature to take that course." (Ibid., XXXII, July is, I839).

2 Phila. GP XXXIII, April 9, I798; XI, September I, I807; January 30, I 810 . In I 817 and again in 1819 an agent was appointed to report the names and conditions of all arrivals of foreign passengers. (Ibid., VII, August I7, I819; VIII, September 5, 1817). In 1825 the guardians obtained judgments to indemnify the city in five cases, and the committec on emigration requested information on foreign paupers, so that the persons who imported them could be called on to give security. (Phila. GP, XV, December 7, I825).

${ }^{3}$ Philadelphia Guardians of the Poor, Report of the Committee appointed... to visit the cities of Baltimore, New York... (Philadelphia, 1827), p. 28. Report of the Committee appointed at a town meeting of the Citizens of Philadelphia... (Philadelphia, 1827), p. 6. 
appear to have solved the problem. Again in 1834 the guardians referred to the great and "constantly increasing" evil of the immigration of foreign paupers into the United States (despite the existence of laws on the subject) with the resulting onerous poor rates in the seaboard cities. ${ }^{1}$

On the other hand, the superintendent of the American Emigrants' Friend Society complained in $185 \mathrm{I}$ that the policy of the guardians was to place "every obstacle... in the way of poor emigrants who are ignorant, to deter them from going to the almshouse". 2 Attention to the taxpayers' interest was also reflected in several cases passed on by the guardians in the 1850 's where persons were allowed to bring infirm relatives from Ireland only if sufficient bond was given. ${ }^{3}$

Baltimore was slightly busier than Philadelphia as an immigrant port of entry. Under a unique arrangement, the city gave two-fifths of the head tax receipts to the German Society of Maryland and the Hibernian Society of Baltimore, in proportion to the sums collected from German and Swiss, and Irish immigrants respectively. ${ }^{4}$ The chief beneficiary was the German Society. The trustees of the poor requested the city council to investigate (1 839) whether fewer German paupers should be supported at the almshouse in view of the large annual grants to the German Society. ${ }^{5}$ In 1849 the trustees complained that the city had 1 Phila. GP XXI, December I, I834. The complaint was in keeping with the popular opinion of the times and was probably exaggerated.

2 American Emigrants' Friend Society, Foreign Pauperism in Philadelphia (Philadelphia, I 85 I) p. 7 . The society felt that the guardians "discountenance any efforts to mitigate the sufferings of emigrants, these very sufferings being regarded as partial barriers against an influx which they consider injurious to their country." (ibid., p. 9).

3 Phila. GP, XXVIII, September 19, 1853 ;XXIX, January 21,1856 ;XXX, March 28, 1859. $4 \mathrm{Md}, 1833$, c. 177 . The preamble to 1832 , c. 303 stated that many foreigners had become charges not only to the city, but to "private associations for relieving foreign immigrants", and therefore the law gave the city discretionary authority to give as much of the head tax receipts as they saw fit, to these societies. By $184 \mathrm{I}, \mathrm{c} .174$, the city had to give the county of Baltimore one-third of the three-fifths of the tax not going to private societies. This provision was dropped in the 1860 Code, which however, continued the old sharing arrangements with the two societies. (Public Local Laws, Art. 4, sec. 260). - Perhaps inspired by the Baltimore example, the American Emigrants' Friend Society petitioned the Pennsylvania legislature for one-third of the head money collected annually by Philadelphia's guardians. The society aimed to relieve immigrants seeking employment and a home, and "at the same time to relieve our citizens of the burden of... supporting an... unemployed and therefore pauper population in their midst..." (op. cit., p. 3). The request was opposed by the guardians and it was not granted. ( $\mathrm{Pa}$. House of Representatives, Journal $185 \mathrm{I}, \mathrm{I}, 348,564$ ).

${ }_{5}^{5}$ From 1834 through 1838 the German Society received a total of $\$ 13,643.83$ compared with $\$ 315.41$ received by the Hibernians. The societies received $\$ 3,384$ and $\$ 140$ respectively in 1840 , but in 1852 the respective amounts were $\$ 3,057$ and $\$ 1,783$. (Baltimore, Ordinances $184^{\circ}$, appendix p. 94; ibid., I84I, appendix p. 94; ibid., 1853 , appendix p. 1o.) 
never collected in any year enough to cover the cost of relieving the immigrant paupers. Yet the head tax was never raised from the $\$ 1.50$ set in 1833 , and unlike the other great ports, Baltimore did not collect a special tax or bond from infirm foreigners. Receipts from the passenger tax - upwards of $\$ 400,000$ from 1833 through 1876 , two-fifths of which went to the societies - compared very favorably with the Philadelphia situation, and the latter had a far greater public pauper burden. ${ }^{1}$

New Orleans, second only to New York as a port of entry for aliens in the years from 1837 to 1861 , instituted a head tax in 1842 . Collections from this source reached a peak of more than $\$ 70,000$ in 1854 . Despite attempts at evasion - around 1842,173 boats landed their passengers in Lafayette - the tax was an important source of income for the Charity Hospital, where many indigent foreigners were treated. ${ }^{2}$ The newly organized Commissioners of Emigration were assigned the revenues from the tax in 1869 and instructed to set up an institution on the model of Castle Garden for the purpose encouraging immigration to the state and protecting the foreigner upon his arrival. This scheme was not carried out. ${ }^{3}$

California's legislation was intended to "operate as a security to the State against the burden which might be inflicted upon her of supporting a large number of Asiatic paupers, or, at least, provide some revenue which would pay, in part, for their support." 4 In the two decades preceding the invalidation of the law (1 872 ), the state treasurer collected over $\$ 430,000$ for the state's hospitals. Although Chinese immigrants supplied the bulk of the funds, they were barred from the San Francisco hospital; only the insane asylum and the pest house admitted them freely. ${ }^{5}$ Here, as in the East, bonds were loosely taken. In one case the surety for four hundred passengers was required to swear that he was worth a mere $\$ 1,000$ in real estate. ${ }^{6}$

1 Ibid., 1840, appendix, p. 95. Ibid. 1850 appendix, p. 130. The data for 1833 through 1839 is from the 1839 Report of Trustees of the Poor (loc. cit.). For subsequent years, the figures were taken from the Register's Summary and the City Comptroller's report published annually in the Ordinances.

2 New Orleans Charity Hospital, Annual Report 1875, pp. 48-49; ibid., 1843, p. 2.

3 Ibid., 1870, pp. 5-6. Commissioners of Immigration, Report to the General Assembly, January, 1870, p. 3 ; ibid., 1874 , p. 3. Protection of immigration began with La., 1866, c. 126.

4 Cal. Assembly, Journal I 86I, p. 418.

5 Mary Roberts Coolidge, Chinese Immigration (New York, 1909), pp. 70-71. See also Lucile Eaves, A History of California Labor Legislation.(Berkeley, Cal., [I9I0]), Ch. 3, s, 6.

- Cal. Assembly, op. cit., p. 420, See also ibid., appendix, Doc, 7 . 
Some lesser ports are known to have had immigration regulations. A Charleston ordinance of 1806 prescribed that a vessel master had to submit a list of passengers and certify "whether he considers any of them as a pauper or paupers and likely to become burdensome to this community". For such, the captain had to enter into bond or remove them within three months. Much stricter requirements were enacted in $184 \mathrm{I}$ : the master had to enter into a bond of $\$ 300$ for two years, for every passenger who was not a citizen of South Carolina or a resident of the city; the owner had the option of commuting the bond for $\$ 2$ per steerage passenger and 25 cents per cabin passenger, a regressive (thought logical) charge not found anywhere else. After I 846, the Harbor Master's consent had to be secured for commutation. ${ }^{1}$ Virginia did not have a head tax law, but in 1842 Norfolk began to collect 50 cents from all passengers arriving from a foreign country, and 25 cents from persons coming in coastal vessels, except Virginians and citizens of adjacent states. Revenues were for the use of the almshouse, while any surplus was to go for harbor improvements. Portland, Maine, during the I850's was collecting 75 cents per alien as commutation money; collections ceased in March, 1875 in accordance with a state law. ${ }^{2}$

III. INTERSTATE COMPLICATIONS AND COMMERCIAL RIVALRY

The "St Cloud", from Londonderry, Ireland, entered at Wilmington, Delaware $(1838$ ) and paid the $\$$ I head tax, though no part of its cargo was intended for that port. Its passengers were then landed at night in Philadelphia (which had a $\$ 2.50$ tax at the time). Such a practice was prohibited by the laws of Pennsylvania, and of several other states. ${ }^{3}$ This particular case was settled when the Philadelphia tax was

1 Charleston City Council, Ordinances... passed since the incorporation of the City (Charleston, 1802), p. 34I; ibid., A Digest of the Ordinances... from the Year 1783 to October I 844 (Charleston, I844), p. II; ibid., Charleston Ordinances... I 844-1854 (Charleston, 1854), p. 29 ; retained in the Ordinances... Revised and Codified... (Charleston, 1875), pp. 179-182.

2 The Ordinances of the Borough of Norfolk... (Norfolk, 1845), p. 233. The ordinance also provided for a vessel tax on a tonnage basis. An I 822 ordinance had merely placed a $\$ 20$ fine on anyone importing a pauper or person without a visible means of support who was likely to become chargeable. (The Ordinances of the Borough of Norfolk [Norfolk, I829] p. 203.) The Revised Ordinances of 1866 did not retain the 1841 ordinance, and indeed made no reference to passengers.

$3 \mathrm{~Pa}$., $1827-1828$, c. 79 , sec. 17 required the vessel master to give the name of every passenger placed on board a vessel bound for Philadelphia, and give a bond or pay head money for each, on penalty of a fine of $\$ 75$ per passenger. The same provision was found in N.Y., 1847 , c. 195 , sec. I. Earlier, by 1799 , c. 80 , the master was liable to pay a $\$ 500$ fine for every alien passenger landed within 50 miles of the city who intended to proceed to 
paid, in addition to court costs, ${ }^{1}$ but the problems it raised were not settled until the Federal government assumed jurisdiction over immigration in I882. Massachusetts-bound immigrants, instead of taking a direct route came through New York and other ports; Boston's superintendent of alien passengers believed that this was due to the "severity" of the commonwealth's laws. Neighboring states were taking bonds, a committee of the legislature pointed out, while Massachusetts supported the paupers, and hurt its commercial interests. A more liberal immigration law resulted in $1852 .^{2}$ The following year, in another move to attract shipping to Boston, head money was refunded or the bond was cancelled if the passenger left the state within two days after arrival. ${ }^{3}$ Now it was New York's turn to complain. Immigrants wishing to land there were being forwarded by rail from Boston; thereby the shipping lines avoided payment of the New York tax. ${ }^{4}$

New York. By Md., I832, c. 303, sec. 3, the master was liable to pay $\$ 100$ for every passenger landed within 50 miles of Baltimore with intent to proceed to that city. A $\$ 100$ fine per passenger was placed on a vessel master who landed aliens at any place within Massachusetts other than the one which was the destination of the vessel for the purpose of evading the immigration act. (Mass., I 848, c. 313 , sec. 9.) For an attempt to evade the law by landing passengers within 30 miles of Savannah a fine of $\$ 300$ was authorized by the I8 $19 \mathrm{Ga}$. act.

1 Phila. GP XXIII, July 16, I 838 ; July 25,1838 .

2 The report of the superintendent of alien passengers is in Mass. House of Representatives, Documents 1852 , No. 47, p. 4. For the report of the joint special committce, see Mass. Senate, Documents I 852 , No. 127 , p. 6. See also Mass. House, Documents I 853 , No. 18, p. 23. A proposal to increase the head tax was opposed by Boston's Board of Trade on the ground that it would destroy "a large part of the city's commerce", and give New York City and Portland a position of preference. (Ibid., 1855, No. 69, p. I.) Beginning in 1849 the N.Y. Commissioners of Emigration (op. cit., p. IO5) began to commute bonds "at such rates as the Commissioners judged sufficient to meet the probable expenses which would be incurred by the support of such persons." This procedure, Governor Boutwell of Mass. felt, gave N.Y. an advantage: business flowed to that city, while many needy found their way to Mass. to become public burdens there. (Mass., Acts and Resolves, I8 2 2, p. 3 I4.) - Following the recommendation of the Commissioners of Emigration, the legislature of N.Y. raised the head tax to $\$ 2$ in 1853 . Earlier a committec of the legislature had argued against the increase on the grounds of adverse effect on the commerce of the city and state. (N.Y.S. Assembly, Documents i 851 , No. 92, p. 5.)

${ }^{3}$ Mass, 1853 , c. 360 . However, by 1854 , c. 219 , if the passenger returncd to Massachusetts and became chargeable, within five years, the vessel master was liable for his support, just as if he had given a $\$ 300$ bond for the passenger. $1865 \mathrm{c}$. I 60 repealed these two laws. It in turn was repealed by 1870 , c. 215 , which re-enacted the 1853 and 1854 provisions. Once more, by 1872 , c. 169 , sec. 2 the latter provisions were repealed. Portland, Mainc exempted aliens en route to Canada from payment of the head tax. (Portland, Annual Reports... I 858 -1 859 , p. 3r.)

${ }^{4}$ N.Y. Commissioners of Emigration, Annual Report... 1870, p. 29. Another type of interstate complication was pointed to in a petition from Providence to the legislature of R.I., dated June, 1847 . The cost of caring for the immigrant poor was unusually large 
Commercial interests viewed the head tax an instrument of rivalry in the keen competition between the major ports for the trade of Europe. Even a small impediment was alleged to suffice to divert traffic from one to another harbor. ${ }^{1}$ The commerce and wealth of Boston would increase if the state were to abolish the head tax while New York continued its charge, the Massachusetts legislature was told. "Give Boston her full share of the export business of the country", pleaded Avery Plumer of that city's Board of Trade. ${ }^{2}$ The removal of the tax in 1872 had frustrated New York's efforts to raise its head tax to $\$ 2.50$, Plumer boasted. A state welfare official remarked, however, that this action had failed to attract immigration to the country, and to the Hub port. ${ }^{3}$

New York reduced the tax to $\$ 1.50$ in 1871 . The Emigration Commission explained that its twin goals were to protect the foreigners under its care and to minimize the "embarrassment" of the port's shippers. Supported by the city's newspapers, the steamship lines succeeded in defeating a bill which would have increased the tax to $\$ 2.00$ in 1874 . New York was "supreme in her efforts to drive away her trade", was the typical comment of the "Daily Bulletin".4

Philadelphia shippers too complained about the local tax. A committee was appointed by the guardians of the poor in 1848 to "take measures to prevent the introduction of foreign Emigrants arriving at other ports into this District". The reduction of the head tax, on the ground that neighboring states charged less than did Philadelphia, and the guardians "ought not to present any difficulties or impediments in

because of a fever among them; most of them came from New York over the railtoad, and it was felt only right that New York should relieve persons who took sick "soon after their arrival". (R.I. General Assembly, Petitions I847-I850 [MS, State Archives, Providence].) - In later years N.Y. and Mass. had a working arrangement whereby the state collecting the head money supported the indigent alien for five years after his arrival, even if he fell into distress in the other state. (Mass. Board of State Charities, Seventh Annual Report, January 1871, pp. 218-219.)

1 Arguments in favor of the freedom of Immigration at the Port of Boston, Addressed to the Committee on State Charities of the Massachusetts Legislature, April, 1871 (Boston, I 87 I), p. 3 I. Statement of E. H. Derby, local merchant.

2 An Appeal to the Legislature of Massachusetts in favor of Freedom of Immigration at the Ports of the Commonwealth... (Boston, 1872), pp. 16-17, 29.

3 "Statement in Behalf of the Boston Board of Trade before the Massachusetts Legislative Committee on Public Charitable Institutions", in: Hamilton Andrews Hill, Immigration and Head-Money Taxes. A series of Papers and Reports (Boston, I877), p. 8. (Library of Congress); Mass. Board of Charities, Twelfth Annual Report (Boston, I 876), p. I I.

4 N.Y.S. Senate, Documents 1871 , III, No. 31 , p. I. N.Y.S. Assembly, Documents 1875 , VII, No. 82, p. 3. Opinions of the New York Press on the Application for an Increase of Emigrant Head Money ([NP], [ND]), p. 3. - After listening to testimony, one legislative committee remained unconvinced that a tax increase would drive away shipping. (N.Y.S. Assembly, Documents 1876 , IV; No. 33, p. iv.) 
the way of the Commerce of the City", was favored only by a minority of this committee. Soon thereafter, however, pressure from the shipping interests finally convinced a majority in favor of a cut. ${ }^{1}$

Was the incidence of the head tax on the immigrant or the vessel owners? The answer of the commercial interests varied with the occasion. An immediate reduction in fares could not be promised with a decrease in the tax, but in the long run rates would fall, the shipping companies told New York's Emigration Commissioners in r $87 \mathrm{I}$. On the other hand, an agent for the North German Lloyd testified that a lower tax would not affect fares, but would enable the lines to spend more on commissions to European agents drumming up traffic, and to offset other heavy expenses. ${ }^{2}$ Another agent for the same line, however, attacked the stand of the counsel for the Emigrant Commissioners that the tax merely decreased the profits of the European shipping lines, rather than affecting the fare. A Detroit businessman felt that earnings from the immigrant traffic were a factor in the determination of freight rates to some extent. ${ }^{3}$ When it came to arguing against a federal levy, the North Atlantic Steam Traffic Conference asserted (1876) that in the days when the head tax was a local affair, competition from lines landing passengers at ports where no tax was collected prevented the companies shipping to (say) New York from adding the tax to the fare, but under a national system this would no longer be true. ${ }^{4}$

New York officials felt that the protection afforded immigrants gave the port "a commanding preference" among foreigners. Ship agents abroad were said to circularize immigrants concerning the great advantage of landing in New York. Moreover, even if no immigrants were brought here, the steamers would have to come with their wares and take back the grain Europe wanted. ${ }^{5}$

1 The committee reports ate in Phila. GP XXVI, April 24, 1848; April 2, 1849; XXVII, August 14, 1849. In 1839 the solicitor of Philadelphia alluded to "the disadvantages it now labours under, in comparison with other ports", as regarded head money. (Ibid., XXXII, July 15,1839 .) The argument of the minority of the committee on emigrants was in error, as far as Md. was concerned, and their observation became obsolete for N.Y. when the tax was raised to $\$ 1$. 50 in 1849 . - New Orleans also was told that its levy was "a serious burden upon commerce". (Louisiana Commissioners of Immigration, Report to the General Assembly, February, 1872, p. 7.)

2 N.Y.S. Assembly, Documents I 876, IV, No. 33, p. 54 , i I r. The Commissioners were disappointed that farcs were not reduced following the head tax cut. Almost $\$ 300.000$ was thus pocketedlby shipowners, theyestimated for 1872 . N.Y.S. Senate, Documents 1873 , No. 37 , p.3. ${ }^{3}$ Freedom, p. 22, 23.

${ }^{4}$ North Atlantic Steam Traffic Conference, To the Hon. the Committee on Commerce and Navigation of the House of Representatives [NP] [ND], p. 2 (Library of Congress). The Indianapolis Daily Sentinel, Nov. 24, 1870 likewise held that the tax was borne by the companies.

${ }^{5}$ N.Y.S. Assembly, Documents 185x, IV, No. 92, pp. 2-3; ibid. 1876, IV, No. 33, p. 659; 
Quite apart from their confidence in the secure position of New York's entrepôt trade, New York immigration authorities shared with their counterparts in other communities the view that the head tax was equitable, following the principle that "each community should, so far as possible, provide for its own poor". "The head tax, in fact, was viewed as an insurance premium rather than as an impost. The foreigner receiving benefits under the law was not comparable in status with an ordinary pauper. ${ }^{2}$

\section{THE BATTLE AGAINST THE HEAD TAX}

Many groups could not appreciate this position, however. A National Commercial Convention, with delegates mostly from the South and the West, met in Baltimore in September, I871 and requested not only that the Federal government assume the task of protecting immigrants, but also that local taxes on foreigners be forbidden. Earlier, in November, I 870, a Western-dominated Immigration Convention in Indianapolis adopted a resolution: "that all capitation taxes collected from immigrants, whether imposed directly or indirectly, with or without color of law, are odious and unjust and ought to be abolished." ${ }^{3}$ Almost identical resolutions were passed by the National Board of Trade meeting in New York City two years later, and by the Chicago Board of Trade in .1876 .4 A number of speakers at Indianapolis had pointed out that most immigrants left for the West. Why should a European en route to lowa be forced to support eleemosynary institutions in New York? Why should New York and Massachusetts have the privilege of defraying the cost of pauper immigrants by a special tax on foreigners while the other states bore the cost by a tax on property? The maritime states derived vast benefits from immigration; it was only fair that they should take the evil along with the

Frank J. Ottarson, Answer to the Memorial of the Steamship Companies... Protesting Against the Proposed Increase in the Head Money (New York, 1874), pp. I0-I I.

1 F. B. Sanborn, (member of the Massachusetts Board of Public Charities) in Proceedings of the Conference of Charities, held in connection with the general meeting of the American Social Science Association, Detroit, May, I 875 (Boston, 1875), p. 97. See also the argument of Letchworth (ibid., p. 96) and the New Orleans Charity Hospital, Annual Report, I831, p. 5 ; ibid., $184^{2}$, p. 2. A Californian agreed that immigrants received "ample equivalent" for their head tax payment to New York. C. T. Hopkins, op. cit. p. 3 I.

2 N.Y. Commissioners of Emigration, Annual Report 1869, p. 34; Friedrich Kapp, Immigration, in: Journal of Social Science, No. 2 (1870), p. 26; Memorial of New York Commissioners of Emigration, Congressional Globe, 42 Congress, 3d Session, p. 423 (1873); Letter from Emigration Commissioner Schack in: New York Daily Tribune, March 22, 1876; Mass. Board of State Charities, Thirteenth Annual Report, p. xli, xlvi; editorial in New York Times, June 19. I 882.

${ }^{3}$ Baltimore Sun, September 30, I87I; Freedom, p. 3. The N.Y. delegation walked out of the convention. (Indianapolis Evening News, November, 25, 1870.)

4 Freedom, p. 5, 6. 
good. To require the man who became an American citizen by adoption to pay into a fund for the support of paupers in his midst was an insidious type of class legislation. ${ }^{1}$ Boston's commercial interests agreed that it was unfair to tax a man on the pretext that he might be a pauper five years hence. ${ }^{2}$

Similar arguments were mustered against the proposal for a Federal levy when the state taxes were declared unconstitutional. The North Atlantic Steam Traffic Conference posed the rhetorical question: was it just to compel ninety-five "good and willing men to contribute to a fund for the support of five, either unable or unwilling to maintain themselves?" 3 The secretary of the National Board of Trade felt that it was odious "to lay a tariff on human flesh". ${ }^{4}$ On the floor of the House of Representatives (1882) a federal tax was attacked as "unAmerican", as well as "in conflict with our past policy". ${ }^{5}$ A generation earlier Representative Breckinridge had argued that if a blind foreigner worth $\$ 100,000$ were allowed to settle in the United States, so should a blind foreigner without a cent to his name. Anything else would be "anti-American... and contrary to the spirit of our whole system"." That a federal tax would have deleterious consequences for the commercial interests of the Atlantic seaboard was the fear which led the local boards of trade of Boston and Portland to oppose it unanimously. ${ }^{7}$ Canada had stopped collecting a head tax on July I0, 1872 and was actively seeking to encourage immigration. ${ }^{8}$ The shipping interests might have recalled with trepidation Parliament's attempt (1850-1853) to encourage the use of the St. Lawrence route by remitting half of the tax if the foreigner was en route to the United States. ${ }^{9}$ Congress, it was felt, should not do anything to discourage

1 Convention Proceedings, in Indianapolis Journal, November 26, 1870. See also H. A. Hill's argument in Freedom, p. Is.

2 An Appeal to the Legislature of Masschusetts, in favor of Freedom of Immigration at the Ports of the Commonwealth... (Boston, $187^{2}$ ), p. 90.

3 Op. cit., p. 3.

${ }^{4}$ Freedom, p. 6. See also p. 33.

5 Congressional Record, XIII, 5107.

${ }^{6} 33$ rd Cong., 2nd Sess., Congressional Globe, XXIV, 783, 1181. For a summary of the discussions in Congress on immigration restriction see Frank George Franklin, The Legislative History of Naturalization in the United States (Chicago, 1906), pp. 264, 271.

${ }^{7}$ Freedom, p. 7.

${ }^{8}$ North Atlantic Steam Traffic Conference, op. cit., pp. 5-6. See also Freedom, pp. I 5 - I6, 34. - The General Agent of State Charities in Massachusetts felt there was no reason to fear competition from the Allan Line to Quebec. In a letter to the House Committee on Commerce (January 3, 1877 [National Archives]) he pointed out that for some years past, despite the tax in American ports, these ports had competed successfully.

- I3 \& 14 Vict., c. 4; repealed by 16 Vict., c. 86. N.Y. was concerned over this law (New York State Assembly, Documents I 85 I, IV, No. 92, P. 5). 
the movement of people who would enrich and develop the country. ${ }^{1}$

Vessel owners reinforced their logic with lawsuits. First to reach the United States Supreme Court had been New York's immigration act of 1824 (almost identical with one passed in 1 799). It was upheld as a most appropriate exercise of the police power in I 837 . A dozen years later, however, in the famous Passenger Cases (Smith v. Turner, and Norris $v$. City of Boston) the New York hospital money law, and the I 837 Massachusetts head money act were declared unconstitutional as forms of state regulation of foreign commerce. ${ }^{2}$ Thereupon, the important seaboard states proceeded to re-enact substantially the same measures, save that the vessel owner was now given the alternative of commuting the required bond for a small money payment. ${ }^{3}$

A unanimous Supreme Court dealt the system of state control a mortal blow on March 20, 1876, when the laws of New York and Louisiana, with their head tax and bonding provisions were declared unconstitutional: to Congress belonged the field of immigration legislation. On the same day, a unanimous Court also held that California's law had gone far beyond what was "necessary or even appropriate" for the purpose of protecting the state from the entrance of undesirable foreigners; the law aimed "to obtain not indemnity but money".4

1 Hamilton A. Hill, The Present Condition and Character of the Immigration Movement. An Argument made at the Conference of Charities, Saratoga Springs, September 7, i876, in opposition to the National Head Money Tax on Immigrants (Boston, 1876), pp. 17-19; North Atlantic Steam Traffic Conference, op. cit., p. 3 ; Levi P. Morton, Immigration, Its National Character and Importance... (Washington, 1880), p. I 2.

${ }^{2}$ City of New York v. Miln, II Peters (36 U.S.) I02, I4I (1837). Earlier, in 1828, the New York Supreme Court has upheld the act (Candler and Waite ads Mayor... and Commonalty of the City of New York, I Wend. 493). The passenger cases are in 7 Howard $283,572,573$ (1849).

3 Cf. the New Orleans Charity Hospital, Annual Report I852, p. 4, where Congress was asked to recognize definitely the right of the states to collect head taxes. Requests for federal action against foreign "pauper dumping" date back to the r830's. (Baltimore, Ordinances 1833, p. 67; Hazard's Register of Pennsylvania, XI [1833], I 5 I ; 2 th Congress, 2nd Sess., Executive Documents, IX, No. 313 ; Mass., Resolves 1836, p. 420.) Another wave of requests for Congressional ban of paupers and convicts was the product of the Know-Nothing agitation of the 1850 's. (R.I., January, I 855 , p. 8 ; 35 th Cong., Ist Session., Senate Miscellaneous Documents, No. 12; Message of William A. Newell, Governor of New Jersey... January 13, 1858 [Trenton, 1858], p. 24; Pa. Senate, Journal, 1857, p. 25.) $A$ bill to this effect was submitted by the House Committee on Foreign Affairs, but not acted upon. (34th Cong., Ist sess. House of Representatives, Reports of Committees, III, No. 359.)

4 Henderson et al. v. Mayor of the City of New York et al, ; Commissioners of Immigration v. North German Lloyd, 92 U.S. 259, 273, 275; Chy Lung v. Freeman et al., ibid., 275, 280. In The State v. SS Constitution, 42 Cal. 578,587 (I872), California's 1852 law was held unconstitutional. An amendment was held invalid by a U.S. Circuit Court in 1874 . (In re Ah Fong, 3 Sawyer 145.) - When N.Y. tried to levy a $\$$ I duty under the guise of an 
Half a dozen years elapsed before Congress finally made up its mind. In the interim a few coastal communities had the burden of caring for immigrants. The patent injustice of this state of affairs did not escape the notice of the House Foreign Affairs Committee, and of President Arthur. The long sought-for relief came in an $188 \mathrm{z}$ act closing the doors of this country to "any convict, lunatic, idiot or any person unable to take care of himself or herself without becoming a public charge". A fifty cent head tax on immigrants would now finance their relief and protection upon arrival. ${ }^{1}$ Interstate rivalry in this ficld had at last come to an end.

\section{THE EFFECTS OF STATE REGULATION}

The problem of administrative effectiveness must be considered in attempting to assess the impact of the mass of state immigration legislation. A German immigrant guide of the 1850's, for example, mentioned the more or less notorious fact that persons without means of support were being smuggled into this or that American port; more recently, however, (it continued) such persons ran the risk of being shipped back. ${ }^{2}$ Massachusetts officials connected with the problem felt that their enforcement activities did tend to reduce the shipment of a large number of destitute and infirm Europeans. ${ }^{3}$ At the very least, as Louisiana's Immigration Commissioners remarked, these laws compelled the steamship lines "somewhat to discriminate in the transport of emigrants". Although many paupers and criminals were prevented from entering, the emigration commission had proven to

inspection charge ( 188 I c. 427 , c. 432) the Supreme Court quickly declared the law unconstitutional (People v. Compagnie Generale Transatlantique, 107 U.S. 59 [I882].) A Cal. inspection fee (to check for leprosy) of 70 cents per passenger arriving from a foreign port met the same fate (Amended Political Code $1875-1876$, sec. 2955; 8 Sawyer 640 [1883].) - In 1878 Congress specified that no action could be maintained against a state or locality for the recovery of head money paid before January I, I877. (U.S. Statutes at Large, XX, 177.)

1 U.S. Statutes at Large, XXII, 214 . An 1875 law had prohibited the cntry of convicts and prostitutes (U.S. Statutes at Large, XVIII, Part III, 477). The Committee on Immigration of the Conference of Charities and Corrections claimed (Proceedings... Ninth Annual Conference [Madison, 1883 ], xxvii) that it had been instrumental in securing the I 882 law.

The House Committe report is in 46th Congress, 2nd Sess., House Report No. I (1879). Arthur's statement is in Richardson, Messages and Papers of the Presidents, VIII, 64.

${ }^{2}$ Dr. Büchelc, Land und Volk der Vereinigten Staaten (Stuttgart, 1855), p. 481. See also N.Y. Commissioners of Emigration, Special Report... December, I854 ([NP], [ND]), p. 4. 3 Superintendent of Alien Passengers for the Port of Boston, in: Mass., Public Documents 1863, Pt. II, No. 15, p. 6; letter dated January 3, 1877 from the Mass. General Agent of State Charities and Acting Superintendent of Alien Passengers to the House of Representatives Committee on Commerce. (MS, National Archives.)

${ }^{4}$ Report to the General Assembly Session of $x 874$, p. 12. 
be a failure in this respect on the whole, a contemporary student concluded. ${ }^{1}$

It is indeed unlikely that the immigration officials succeeded in keeping out or bonding properly every candidate for the pauper class. Certain it is though that the foreign passengers contributed (in the form of the head tax) a not inconsiderable sum for the support of the poor in their midst. The measures designed in the colonial period to secure the community against having to support foreigners likely to become chargeable evolved in the important ports of entry into the practice of placing a small charge on all immigrants for the privilege of landing. To the extent that this tax increased the cost of passage it had the effect of keeping out the poorest and making it more expensive for a foreign locality to ship its undesireables here. ${ }^{2}$ Nevertheless the price of a ticket remained the major barrier between the Old and the New World in the nineteenth century.

While the specialized public institutions of New York and Massachusetts as well as the long-standing systems of poor law and private relief in other communities functioned as agencies to facilitate the adjustment of the immigrants, the state bond and head tax requirements served to protect the seaboard communities from at least a significant portion of the financial burden of supporting needy foreigners. When the federal government assumed the responsibility of regulating and protecting immigration it had the foundation of local experience and institutions upon which to build. For almost a decade, in fact, Congress saw fit to leave the administration of the general immigration act of 1882 in the hands of the states.

1 Martin B. Anderson, Legislation to Prevent the United States from Being Made a Receptacle for Foreign Paupers, in: Conference of Charities, Proceedings... at Saratoga, September, 1876 (Albany, 1876 ), p. 172 . Dr. Hoyt complained in 1885 that at many ports, the investigation was not always as thorough as desirable, with the result that improper persons were allowed to land who became public burdens. (National Conference of Charities and Correction, Proceedings... Eleventh Annual Session [Boston, 1885 ], p. 48.) 2 Cf. N.Y. Com. Emig., p. I75. Passage from Bremen (including food) cost $\$ 20$ in I845. Around 1873 the fare from Europe was $\$ 40$. (Thomas W. Page, Transportation of Immigrants and Reception Arrangements in the Nineteenth Century, in: Journal of Political Economy XIX [1911], 738.) 


\section{TABLE: IMMIGRATION LEGISLATION ${ }^{1}$}

( ${ }^{* *}$ denotes continuance of the provision of an earlier act)

\begin{tabular}{cccc}
$\begin{array}{c}\text { Date of } \\
\text { Law }\end{array}$ & $\begin{array}{c}\text { Bond Sum } \\
\text { and Duration }\end{array}$ & $\begin{array}{c}\text { Commutation } \\
\text { Fee }\end{array}$ & $\begin{array}{c}\text { Persons for whom } \\
\text { Required }\end{array}$ \\
\hline
\end{tabular}

MAINE ${ }^{2}$

$\begin{array}{lcc}\text { I } 820 & \text { UP to } \$ 500 \text { for } 3 \text { yrs. } & - \\ & * * & - \\ \text { I } 835 & * * & \text { Up to } \$ 5 \\ \text { I } 838 & * * & * * \\ \text { I } 84 \mathrm{I} & * * & \text { Up to } \$ 2 \\ \text { I } 848 & \text { Repealed } & \text { Repealed }\end{array}$

NEW HAMPSHIRE

$\begin{array}{lcc}\text { I7I8 } & \text { "sufficient security" } & - \\ & & \\ \text { I79I } & \text { "reasonable sum" } & - \\ 1820 & \text { Up to } \$ 500 ; \text { for } 3 \text { yrs. } & - \\ \text { I } 842 & \$ 200 \text { for } 3 \text { yrs. } & -\end{array}$

\section{MASSACHUSETTS}

1700
1722
1724

\begin{tabular}{|c|c|}
\hline 1756 & Not specified \\
\hline 1789 & - \\
\hline & $\begin{array}{l}\text { Up to } \$ 500 ; \text { for } \\
3 \text { yrs. }\end{array}$ \\
\hline $183 I$ & $\begin{array}{l}\text { Up to } \$ 200 ; \text { for } \\
3 \text { yrs. }\end{array}$ \\
\hline
\end{tabular}

Every passenger without a settlement in the state.

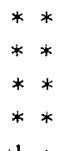

Common carrier that brought passenger without a Maine settlement to remove him if he falls into distress within a yeat after his arrival.

"Impotent, Lame, or otherwise infirm" passengers, or "likely to be a Charge to the Place".

"sick or lame, and likely to be chargeable". Bond may be required; each non-settled person likely to become chargeable.

Every passenger without a settlement in the state. Selectmen may dispense with the bond if they sce fit.

"Impotent, Lame or otherwise infirm, or likely to be a Charge to the Place".

All passengers.

- All passengers except: those with $£$ so capital, able-bodied farmers, craftsmen, mariners, laborers and indented servants (unless a person of ill fame).

Bond required of "sick or impotent or infirm person"; at the discretion of the selectmen. List of passengers and their condition required, to prevent the importation of persons who might prove chargeable.

Each passenger the selectmen decm liable to become a public charge.

If commuted, fee to be paid for every alien passenger; if bonded, selectmen may dispense with bond, if no charge for passenger "is to be apprehended".

1 See note to table, p. 295.

2 See Massachusetts for laws beforc i 820 . 


\begin{tabular}{|c|c|c|c|}
\hline $\begin{array}{c}\text { Date of } \\
\text { Law }\end{array}$ & $\begin{array}{l}\text { Bond Sum } \\
\text { and Duration }\end{array}$ & $\begin{array}{c}\text { Commutation } \\
\text { Fee }\end{array}$ & $\begin{array}{c}\text { Persons for whom } \\
\text { Required }\end{array}$ \\
\hline
\end{tabular}

$\begin{array}{ll}1837 & \text { (a) } \$ 1,000 ; \\ \text { for Io yrs. }\end{array}$

(a) Every alien "lunatic, idiot, maimed, aged or infirm person, incompetent... to maintain themselves, or who have been paupers in any other country."

\begin{tabular}{|c|c|c|c|}
\hline & (b) - & (b) $\$ 2$ & (b) All other alien passengers. \\
\hline \multirow[t]{2}{*}{1848} & $\begin{array}{l}\text { (a) } \$ 1,000 \text { for life } \\
\text { of alien }\end{array}$ & (a) - & (a) $\quad * *$ \\
\hline & (b) - & (b) $\$ 2$ & $* *$ \\
\hline \multirow[t]{2}{*}{1850} & (a) $\$ 1,000$; life & (a) - & $* *$ \\
\hline & (b) $\$$ I,ooo; life & (b) $\$ 2$ & $* *$ \\
\hline \multirow[t]{2}{*}{1852} & $\begin{array}{l}\text { (a) } \$ 1,000 \text { for } \\
10 \mathrm{yrs} \text {. }\end{array}$ & $\begin{array}{l}\text { (a) Beginning in } \\
1853 \text { at no set } \\
\text { rate }\end{array}$ & $\begin{array}{l}\text { (a) "Insane, idiotic, deaf and dumb, blind, } \\
\text { deformed or maimed person, ... or alien who } \\
\text { has before been a public charge within this } \\
\text { state." }\end{array}$ \\
\hline & $\begin{array}{c}\text { (b) } \$ 300 \text { for } \\
5 \text { yrs. }\end{array}$ & $\begin{array}{l}\text { (b) Not less } \\
\text { than } \$ 2\end{array}$ & $* *$ \\
\hline \multirow[t]{2}{*}{1872} & (a) $* *$ & (a) $* *$ & $* *$ \\
\hline & (b) Eliminated & (b) Eliminated & \\
\hline
\end{tabular}

RHODE ISLAND

\begin{tabular}{|c|c|c|}
\hline 1702 & $£$ IOo & - \\
\hline 1729 & $£ 50$ & - \\
\hline I 798 & - & - \\
\hline 1847 & $\begin{array}{l}\text { Unspecified amount } \\
\text { for I yr. }\end{array}$ & $\begin{array}{l}\text { "Just and } \\
\text { reasonable" }\end{array}$ \\
\hline 1857 & $* *$ & - \\
\hline 1872 & $* *$ & At least $\$ 2$ \\
\hline
\end{tabular}

Passenger not admitted as inhabitant of the colony

Persons from places other than Great Britain, Ireland, Jersey and Guernsey

List of foreign passengers and their condition required; no bond mentioned

All foreign passengers

Foreign passengers may be bonded at the discretion of the overseers of the poor

NEW YORK

\begin{tabular}{|c|c|}
\hline 1721 & $£ 50(\$ 125)$ \\
\hline I 788 & $£$ I0o $(\$ 250)$ \\
\hline 1797 & Unspecified amount \\
\hline$\times 799$ & Up to $\$ 300$ for 2 yrs. \\
\hline 1847 & (a) - \\
\hline
\end{tabular}

"Any persons that cannot give a good Account of themselves to the Mayor or like[ly] to be a Burthen" to New York City

Immigrants likely to become chargeable Alien passengers

(a) Non-defective alien

(b) "lunatic, idiot, deaf and dumb, blind or infirm persons, not members of emigrating families and who from attending circumstances are likely to become permanently a public charge"
1849
(a) $\$ 300 ; 5$ yrs.
(a) $\$ 1.50$
(b) $\$ 500$; ro yrs.
(b) -

(a) Every alien passenger

(b) "Lunatic, idiot, deaf and dumb, blind or 


\begin{tabular}{|c|c|c|c|}
\hline $\begin{array}{l}\text { Date of } \\
\text { Law }\end{array}$ & $\begin{array}{l}\text { Bond Sum } \\
\text { and Duration }\end{array}$ & $\begin{array}{c}\text { Commutation } \\
\text { Fee }\end{array}$ & $\begin{array}{c}\text { Persons for whom } \\
\text { Required }\end{array}$ \\
\hline
\end{tabular}

7851
(a)
* *
(a) * *
(b) $\$ 500 ; 5$ yrs.
(b) -

$\begin{array}{llll}1853 & \text { (a) } & * * & \text { (a) } \$ 2 \\ & \text { (b) } & * * & \text { (b) }- \\ 1867 & \text { (a) } & * * & \text { (a) } \$ 2.50 \\ & \text { (b) } & * * & \text { (b) } * * \\ 1871 & \text { (a) } & * * & \text { (a) } \$ 1.50 \\ & \text { (b) } & * * & \text { (b) } * *\end{array}$

NEW JERSEY

1730

1797

1819

I 838

PENNSYLVANIA

1729

1730

$\begin{array}{lc}1828 & \text { Up to } \$ \text { I } 50 \\ \text { for } 2 \text { yrs. } \\ 1832 & * * \\ 1849 & * *\end{array}$

infirm persons, not members of emigrating families or who from attending circumstances are likely to become permanently a public charge, or who have been paupers in any other country or from sickness or disease [are] likely soon to be chargeable"

(a)

b) Categories as in 1849 , and also persons over 6o, widows and single women with children, and any person unable to take care of himself or herself without becoming a public charge

$\begin{array}{ll}\text { (a) } & * * \\ \text { (b) } & * * \\ \text { (a) } & * * \\ \text { (b) } & * * \\ \text { (a) } & * * \\ \text { (b) } & * *\end{array}$

"Old persons, Infants, Maimed, Lunatic or any Vagabond or Vagrant Persons"

Repealed 1730 act and merely banned the importation of convicts

Foreign passenger who is "sick, infirm, or otherwise incapable... of providing for his or her own support"

Every alien passenger (a) $\mathcal{L}_{2}(\$ 5.33)$

(b) $£$ I $(\$ 2.67)$ (a) Non-British subject coming by land or by water
(b) Irish servants

"infant, lunatic, maimed, aged, impotent, or vagrant person... likely to become chargeable"; beginning in $\mathrm{I}_{803}$ applicable only to Philadelphia; original 1730 act related to entire province

All alien passengers
Up to $\$ 2.50$

Sum "sufficient to

indemnify the guardians of the poor" 


\begin{tabular}{|c|c|c|c|}
\hline $\begin{array}{c}\text { Date of } \\
\text { Law }\end{array}$ & $\begin{array}{l}\text { Bond Sum } \\
\text { and Duration }\end{array}$ & $\begin{array}{c}\text { Commutation } \\
\text { Fee }\end{array}$ & $\begin{array}{l}\text { Persons for whom } \\
\text { Required }\end{array}$ \\
\hline
\end{tabular}

DELAWARE

$\begin{array}{lccc}1740 & & \text { "sufficient security" } & - \\ 1779 & & * * & - \\ 1802 & \$ \text { I000 } & & - \\ 1829 & - & & \$ I\end{array}$

MARYLAND

$\begin{array}{llr}1833 & \text { Up to } \$ \text { I } 50 ; 2 \text { yrs. } & \$ 1.50 \\ 1835 & - & * * \\ 1850 & \$ 300 ; 5 \text { yrs. } & \$ 1.50\end{array}$

NORTH CAROLINA

$1755 \quad \underbrace{}_{40}(\$ 100)$

1777

SOUTH CAROLINA

1738 Not specified

GEORGIA

I819

1860

$\$ 500$

ALABAMA

1803

1852

$\$ 500$
Same categories as Pennsylvania $173^{\circ}$

Persons "likely to become chargeable"

**

All alien passengers
All alien passengers more than 5 years old
All alien passengers

Person "incapable of getting a Livelihood by his industry", without sufficient property for his support

Omitted from poor law

Persons from outside the province; "persons who were impotent, lame, or otherwise infirm, or likely to be a charge to the parish"

All foreign passengers brought into Savannah between July I and October 31, "the sickly months"; applicable also to Darien after 1830 "any infant, lunatic, maimed, deaf and dumb, blind, aged or infirm person... likely to become chargeable to the county"

Court may require bond for "any infant, lunatic, maimed, aged, infirm person, or vagrant... ikely to be chargeable"

As ab rve, with omission of vagrant category; addition of deaf, dumb

MISSISSIPPI

1803

I 857

I d e n t i c a l w i t h

Sufficient sum

$\$$ ro for all

A 1 a. $\quad$ I 8 o 3

passengers

landed

Alien passengers "who may become a charge as paupers"; may be dispensed with if deemed unnecessary by local officer

LOUISIANA

I 842

$\$$ I per cabin passenger; $50 \varnothing$ per stcerage passenger 


\begin{tabular}{|c|c|c|c|}
\hline $\begin{array}{l}\text { Date of } \\
\text { Law }\end{array}$ & $\begin{array}{l}\text { Bond Sum } \\
\text { and Duration }\end{array}$ & $\begin{array}{l}\text { Commutation } \\
\text { Fee }\end{array}$ & $\begin{array}{l}\text { Persons for whom } \\
\text { Required }\end{array}$ \\
\hline 1843 & - & $\begin{array}{l}\$ 3 \text { per cabin } \\
\text { passenger } \\
\$ 2 \text { per steerage } \\
\text { passenger }\end{array}$ & $* *$ \\
\hline 1850 & $\$$ I000; 5 yrs. & $\$ 2$ & $\begin{array}{l}\text { Every alien arriving by vessel anywhere in } \\
\text { state }\end{array}$ \\
\hline 1855 & $* *$ & $\$ 2.50$ & Exempted aliens under to years old \\
\hline 1869 & (a) $\$ 300$; 5 yrs. & (a) $\$ 2$ & $\begin{array}{l}\text { (a) Alien of any age not likely to become a } \\
\text { public charge }\end{array}$ \\
\hline$x 869$ & (b) $\$ 500 ; 5$ yrs. & (b) Special rates & $\begin{array}{l}\text { (b) "lunatic, idiot, deaf, dumb, blind, maimed } \\
\text { or infirm person, or persons above the age of } \\
60 \text { years, or any woman without a husband } \\
\text { and with a child, or any person unable to } \\
\text { take care of himself or herself without } \\
\text { becoming a public charge;" bond in addition } \\
\text { to } \$ 2 \text { commutation if master decides not to } \\
\text { give bonds in (a) }\end{array}$ \\
\hline
\end{tabular}

TEXAS

$\begin{array}{llll}\text { I844 } & - & \$ \mathrm{I} & \begin{array}{l}\text { Galveston could tax every free white passenger } \\ \text { arriving from port outside Texas until I856 } \\ \text { Every alien; passenger list to note lunatic, } \\ \text { idiot, deaf, dumb, blind or infirm, and to } \\ \text { state if accompanied by relatives able to } \\ \text { support them } \\ \text { I866 }\end{array} \quad \text { Omitted from immigration act }\end{array}$

CALIFORNIA

\begin{tabular}{|c|c|c|c|}
\hline 1850 & $\$ 200 ; 5$ yrs. & $\begin{array}{l}\$ 3 \text { per cabin } \\
\text { passenger; } \$ 2 \text { per } \\
\text { steerage passenger } \\
\text { if American vessel } \\
\text { or foreign one } \\
\text { placed by treaty on } \\
\text { a plane of equality } \\
\text { with U.S.; if not, } \\
\text { foreign vessel pays } \\
\$ 5 \text { and } \$ 3 \\
\text { respectively }\end{array}$ & $\begin{array}{l}\text { Each passenger } \\
1 \\
\end{array}$ \\
\hline 1851 & $\$ 200 ; 2$ yrs. & $\begin{array}{l}\text { \$ } 5 \text { per cabin } \\
\text { passenger; } \$ 3 \text { per } \\
\text { deck passenger }\end{array}$ & All passengers except those from U.S. ports \\
\hline 1852 & $\begin{array}{l}\text { (a) } \$ 500 ; 2 \text { yrs. } \\
\text { (b) } \$ 1500 ; 2 \text { yrs. }\end{array}$ & $\begin{array}{l}\text { (a) } \$ 5-\$ 10 \\
\text { (b) Sufficient, } \\
\text { equitable sum }\end{array}$ & $\begin{array}{l}\text { (a) Alien passengers not likely to become a } \\
\text { public charge } \\
\text { (b) "lunatic, idiot, deaf, dumb, blind, cripple, } \\
\text { or infirm persons, not members of families, or } \\
\text { who from attending circumstances, are likely }\end{array}$ \\
\hline
\end{tabular}




\begin{tabular}{|c|c|c|c|}
\hline $\begin{array}{c}\text { Date of } \\
\text { Law }\end{array}$ & $\begin{array}{l}\text { Bond Sum } \\
\text { and Dutation }\end{array}$ & $\begin{array}{c}\text { Commutation } \\
\text { Fee }\end{array}$ & $\begin{array}{c}\text { Persons for whom } \\
\text { Required }\end{array}$ \\
\hline
\end{tabular}

$\begin{array}{llll}1862 & \text { (a) } & * * & \text { (a) } \$ 5 \\ & \text { (b) } & * * & \text { (b) } * * \\ 1874 & \text { (a) }- & \text { (a) }-\end{array}$

to become permanently a public charge, or who have been paupers in any other country..."

(a) $* *$

(b) $* *$

(a) Abolished in accordance with State Supreme Court decision ( $42 \mathrm{Cal}$. $57^{8}$ ) but 70 cent inspection charge made

$\begin{array}{ll}\text { (b) } \$ 500 ; 2 \text { yrs. } & \text { (b) } \$ 5\end{array}$

(b) As in 1852 , in addition to convicted cirminals and lewd women.

\section{NOTE TO TABLE}

Me., I820; c. 26; I835, c. I 54 ; 1838 , c. 339 ; Rev. St., I 841, c. 32 ; sec. 56 ; r848, c. 4 O. I875, c. 4 r. N.H., 171 8 , c. $37 ; 1791$, c. $76 ; 1820$, c. I; Rev. St., 1842, c. 67, sec. 6 retained in: Pub. St., I 891, c. 85, sec. 16, 17. Mass., $1700 / 1$, c. $23 ; 1722 / 23$, c. $5 ; 1724 / 25$, c. $8 ; 1756 / 57$, c. $4 ; 1788$, c. 61 ; 1820, c. 290; I831, c.1 50; 1837 , c. $238 ; 1848$, c. $313 ;$; 850 , c. I05; 1852, c. 279; 1853 , c. 367; 1872, c. 169. R.I., Laws and Acts, 1705, p. 53 (for the I702 law); 1729 act, in: Acts and Laws... (Newport, 1745), p. 1 27; Pub. Laws 1798, p. 358 ; June, 1847, p. 27 ; Rev. St. 1857 , c. 51 , sec. 5 ; Gen. St. 1872, c. 66, sec. 6, retained in: Pub. St. I882, c. 72, sec. 6. N.Y., I 721 , c. $410 ; 1788$, c. $62 ; 1797$, c. 10I; 1799, c. 80, (substantially re-enacted as 1824, c. 37); 1847 , c. $195 ; 1849$, c. $350 ; 1851$, c. 523 , sec. 4 ; 1853, c. $224, x 867$, c. 911 , again in 1869 , c. 808 ; 1871 , c. 475. N.J., I730, in: Nevill I, $210-215 ; 1797$ c. 661; 1818/19, p. 14; 1837/38, pp. $77-78$ retained in: Gen. St. 1895 , p. 24, while the 1819 law is in: ibid., p. $25 \mathrm{II}$. Pa., I 729 act in: St. at Large, IV, I35-40; 1730 act in: ibid., pp. 164-171; 1802/3, c. 155, sec. $23 ; 1827 / 28$, c. 79 , sec. 17,$18 ; 1831-32$, c. 39, sec. 5; I849, c. 178 . Del. 1740 act in: Laws, I, c. 66; 1775 in: ibid., c. 225, sec. I1; 1802 in: ibid., III, c. 110; 1829, in: Laws, VII, c. 195, sec. Is tetained in; Rev. St. 1893 , c. 48 , sec. 17, Md., 1832, c. $303 ; 1834$, c. $84 ; 1849$, c. 46, retained in: Pub. Local Laws $\mathrm{I} 888$, art. 4, sec. 4 1 2-24. N.C., 1755 , c. 6, sec. 7 ; 1777, c. 7. S.C., 1738 act in: St. at Large, III, 491-492, retained in: Rev. St. 1873, c. 29, sec. 24. Ga., I819 act in: Compilation... (I821), pp. 44-48; 1830, p. 209; Code, 1860, sec. 720-21; Code, 1882, sec. 769-70. Ala. and Miss. 1803 in Miss. Territory, Acts of the Second Gen. Ass., No. $18 \mathrm{I}$, found also in: Digest, 1807, p. 422 ; Ala. Code, 1852, sec. 1219, retained in: Code 1897, sec. 3238. Miss., Rev. Code, 1857, c. 23, art. 19, retained in: Rev. Code, 1880 , sec. $640,64 \mathrm{I}$. La., I841/42, c. 158; 1843, c. 81; 1850, c. $295 ; 1885$, c. I55, sec. 12 ; 1869, c. 93 , retained in 1874 , c. 154. Tex., 1844, p. 92, repealed by 1856 , c. 238 ; 1850 , c. 161 ; 1866, c. 381 . Cal., 1850, c. $65 ; 185$ 1, c. $87 ; 1852$, c. $36 ; 1862$, c. $367 ;$ Amendments, Political Code, 1873-74, new sec. 2952, amended beyond recognition by Amend. Pol. Code, 1875-6, sec. 2950, 2952.

Certain laws merely authorized and empowered the taking of passenger lists, bonds, etc., but did not require the local officials to do so. This was the case in the $1819 \mathrm{Ga}$. act, the 1799 (and 1824 c. 37) law for N.Y.C., all the laws of Me. and N.J., the Pa. laws of 1730 , I803, I828, and I849, the I857 R.I. statute and the N.H. laws of 1820 and 1842 . The 1755 N.C. act, unlike most of the other legislation in this area did not provide that the vessel master submit a list of passengers on arriving. Instead, upon the complaint of a freeholder that the master had brought into the province persons feared likely to become chargeable to the public, a hearing was to be held and if the person had sufficient means for support and was incapable of earning a livelihood, the master had to give a bond with the condition that he would transport the person out of the province within six months or indemnify any parish for supporting such person. 